\title{
Hubungan Antara Merokok dan Aktifitas Fisik dengan Prevalensi Hipertensi di Indonesia (ANALISIS DATA RISKESDAS DAN PROFIL KESEHATAN 2013)
}

\author{
Balgis $^{1}$, Sumardiyono ${ }^{1}$ \\ 1. Bagian Ilmu Kesehatan Masyarakat Fakultas Kedokteran Univesitas Sebelas Maret \\ Korespondensi :balgis@staff.uns.ac.id
}

\begin{abstract}
ABSTRAK
Pendahuluan:Saat ini hipertensi merupakan masalah kesehatan utama di dunia termasuk juga di Indonesia. Prevalensi hipertensi di berbagai daerah di Indonesia berbeda-beda, beberapa faktor diduga berperan dalam variasi ini diantaranya adalah sistem kesehatan, faktor risiko hipertensi dan prevalensi diabetes mellitus. Penelitian ini bertujuan menganalisishubungan antara sistem kesehatan (pelayanan kesehatan, tenaga kesehatan, keuangan), faktor risiko hipertensi ( merokok dan aktifitas fisik) dan prevalensi diabetes mellitus dengan perbedaan prevalensi hipertensi di berbagaiprovinsi di Indonesia.

Metode:Penelitian ini menggunakan desain observasional analitik dengan pendekatan ecological study. Data diperoleh dari 440 kabupaten dan 33 provinsi di Indonesia yang diambil secara probability proporsional to size. Sampel adalah pria dan wanita dengan usia 18 tahun keatas. Variabel bebas adalah prevalensi hipertensi sedangkan variabel terikat adalah sistem kesehatan (pelayanan kesehatan, tenaga kesehatan, keuangan), faktor risiko hipertensi ( merokok dan aktifitas fisik sedentary) dan prevalensi diabetes mellitus. Diagnosis hipertensi dibuat oleh dokter. Data yang diperoleh dianalisis dengan menggunakan analisis regresi linier ganda.

Hasil:Merokok $(b=0,0,463 ; 95 \% \quad C I=0,042-0,884 ; p=0,032), \quad$ dan aktifitas fisik sedentary lebih 6 jam $(b=0.196 ; 95 \% \quad C I=0,030-0,362 ; p=0,022)$ meningkatkan prevalensi hipertensi. R2 dari model regresi liner ganda sebesar $=27,1 \%$, dan secara keseluruhan model berbeda secara bermakna $(\mathrm{p}=0.05)$.

Kesimpulan:Merokok dan aktifitas fisik sedentary berhubungan dengan prevalensi hipertensi
\end{abstract}

Kata Kunci: merokok; aktifitas fisik sedentary; prevalensi hipertensi

\begin{abstract}
Introduction:Currently hypertension is a major health problem in the world, including in Indonesia. The prevalence of hypertension in various regions in Indonesia varies. several factors play a role in this variation including the health system, hypertension risk factors and the prevalence of diabetes mellitus. This study aims to analyze the relationship between the health system (health services, health personnel, finance), hypertension risk factors (smoking and physical activity) and the prevalence of diabetes mellitus with differences in the prevalence of hypertension in various provinces in Indonesia. Methods:This study used an observational analytic design with an ecological study approach. Data was obtained from 440 districts and 33 provinces in Indonesia which was taken on a probability basis to size. Samples are men and women aged 18 and above. The independent variable was the prevalence of hypertension while the dependent variableswere the health system (health services, health personnel, finance), hypertension risk factors (smoking and sedentary physical activity) and the prevalence of diabetes mellitus. The diagnosis of hypertension was made by a doctor. The data obtained were analyzed using multiple linear regression analysis.

Results:Smoking $(\mathrm{b}=0,0.463 ; 95 \% \mathrm{CI}=0.042-0.884 ; \mathrm{p}=0.032)$, and sedentary physical activity of more than 6 hours $(b=0.196 ; 95 \% \mathrm{CI}=0.030-0.3362 ; \mathrm{p}=0.022)$
\end{abstract}


increased the prevalence of hypertension. R2 from the multiple liner regression model is $=27.1 \%$, and overall the models differ significantly $(\mathrm{p}=0.05)$.

Conclusion: Smoking and sedentary physical activity are associated with the prevalence of hypertension

\section{Keywords: smoking; sedentary physical activity; prevalence of hypertension}

\section{PENDAHULUAN}

Hipertensi atau tekanan darah tinggi adalah peningkatan tekanan darah sistolik lebih dari $140 \mathrm{mmHg}$ dan tekanan darah diastolik lebih dari $90 \mathrm{mmHg}$ pada dua kali pengukuran dengan selang waktu lima menit dalam keadaan cukup istirahat/tenang.

Peningkatan tekanan darah arterial secara terus-menerus, merupakan kondisi medis yang dapat menyebabkan seseorang mengalami risiko kesakitan (morbiditas) bahkan kematian (mortalitas) ${ }^{1}$.

Menurut data World Health Organization(WHO), secara global sekitar 17 juta kematian terjadi setiap tahun dan hampir sepertiganya akibat penyakit kardiovaskular. Dari data tersebut, komplikasi dari hipertensi mengakibatkan 9,4 juta kematian setiap tahun di seluruh dunia, dimana $45 \%$ kematian akibat penyakit jantung dan $51 \%$ kematian akibat stroke. Pada tahun 2008, di seluruh dunia, sekitar $40 \%$ dari orang dewasa berusia di atas 25 tahun telah didiagnosis menderita hipertensi. Jumlah penderita hipertensi naik dari 600 juta pada tahun 1980 menjadi 1 miliar pada tahun $2008^{2}$. Menurut data Global Status Report on Noncommunicable Diseases 2010, dari World Health Organization (2013) prevalensi hipertensi tertinggi adalah di wilayah Afrika, yaitu $46 \%$ dari orang dewasa berusia di atas 25 tahun, sedangkan prevalensi terendah, di Amerikayaitu 35\%.

Tingginya angka kejadian hipertensi di dunia, dipengaruhi oleh dua jenis faktor risiko, yaitu faktor risiko yang tidak bisa diubah dan faktor risiko yang bisa diubah. Faktor risiko yang tidak dapat diubah seperti umur, jenis kelamin, ras (suku bangsa) dan faktor keturunan sedangkan faktor yang bisa diubah diantaranya obesitas, konsumsi alkohol, kurang olahraga, kebiasaan merokok, gaya hidup sedenter, stress, pola makan yang tidak sehat(tinggi natrium atau

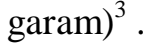

Sampai saat ini, hipertensi di Indonesia masih merupakan permasalahan besar. Prevalensi hipertensi di Indonesia sesuai dengan data Riset Kesehatan Dasar (Riskesdas) 2013 termasuk tinggi yaitu sebesar 25,8\%. Sementara itu, data dari Survei Indikator Kesehatan Nasional (Sirkesnas) tahun 2016 menunjukkan peningkatan prevalensi hipertensi pada penduduk usia 18 tahun ke atas sebesar $32,4 \%$. Terdapat 13 provinsi yang persentasenya melebihi angka nasional, yang tertinggi ada di Provinsi Bangka Belitung $(30,9 \%)$ atau secara absolut sebanyak 426.655 jiwa, dan yang terendah di Papua (16,8\%). Data ini menunjukan ada perbedaan prevalensi hipertensi di setiap provinsi di Indonesia. Perbedaan ini diduga karena beberapa faktor termasuk sosiologi, ekonomi, budaya, pribadi, pendidikan, dan psikologi, selain itu ada beberapa faktor lain yang juga berpengaruh seperti gaya hidup yang tidak sehat dan kebiasaan merokok. Juga pengontrolan hipertensi yang belum adekuat meskipun obat-obatan yang efektif banyak tersedia.

Peningkatan prevalensi hipertensi diduga ada kaitannya dengan penyakit DM (diabetes mellitus). Diabetes yang dibiarkan bertahan lama tanpa pengobatan menyebabkan kadar gula dalam darah tidak terkontrol dan dapat mengakibatkan peningkatan penumpukan lemak pada dinding pembuluh darah. Penumpukan lemak ini dapat 
meningkatkan risiko pembuluh darah menyempit karena tersumbat hingga akhirnya mengeras, dan terjadilah aterosklerosis yang dapat menghambat aliran darah dari jantung karena pembuluh yang menyempit. Jantung bekerja lebih keras lagi untuk memompa darah sehingga tekanan darah semakin lama semakin tinggi dan terjadilah hipertensi ${ }^{6}$. Jumlah penderitadiabetes mellitus (DM) di Indonesia cukup signifikan, pada tahun 2000 jumlahnya sekitar 8,4 juta orang dan pada tahun 2030 diperkirakan akan menjadi 21,3 juta orang. Badan Pusat Statistik (BPS) menyatakan jumlah DM pada tahun 2003 sebesar 13,7 juta orang dan meningkat menjadi 20,1 juta orang pada tahun $2030^{7}$.

Terjadinya resistensi insulin karena diabetes membuat tubuh gagal menyerap glukosa untuk dijadikan sumber energi atau simpanan lemak, sehingga terjadi peningkatan lemak tubuh yang bisa mengganggu kerja sistem saraf yang mengatur tekanan darah. Resustensi insulin akan memicu ketidakseimbangan garam dan kalium yang menyebabkan terjadinyapeningkatan volume cairan tubuh sehingga berisiko hipertensi

Menurut data BPJS Kesehatan, biaya pelayanan hipertensi meningkat setiap tahunnya, yakni Rp. 2,8 triliun pada 2014, Rp. 3,8 triliun pada 2015 , dan Rp. 4,2 triliun pada tahun 2016.

Sistem kesehatan memiliki peran penting dalam manajemen pengendalian hipertensi dan kemungkinan menjadi salah satu faktor penyebab perbedaan prevalensi hipertensi di berbagai provinsi di Indonesia.

Menurut WHO, sistem kesehatan dipengaruhi oleh enam komponen inti terdiri dari: 1) Layanan kesehatan, 2) Perawatan Kesehatan, 3) Sistem informasi kesehatan, 4) Akses ke perawatan esensial, 5) Keuangan, 6) Kepemimpinan ${ }^{8}$. Jumlah dan penyebaran fasilitas pelayanan kesehatan serta tenaga kesehatan yang tidak merata di setiap provinsi begitu juga dengan pendanaan yang belum memadai, dapat menjadi faktor penyebab lambatnya penanggulangan diabetes dan hipertensi.

Perubahan gaya hidup kurangnya aktifitas fisik, kebiasaan merokok dan adanya penyakit diabetes mellitus menjadi faktor risiko tingginya prevalensi hipertensi di Indonesia..

Penelitian ini bertujuan untuk menganalisa hubungan antara sistem kesehatan nasional khususnya (fasilitas pelayanan kesehatan, tenaga kesehatan, keuangan),faktor risiko hipertensi ( merokok dan aktifitas fisik)dan prevalensi diabetes mellitus dengan prevalensi hipertensi di berbagai provinsi di Indonesia.

Penulis berharap penelitian ini akan berguna untuk semua pihak yang terlibat dalam upaya pengendalikan hipertensi di Indonesia.

\section{METODE}

Jenis penelitian ini adalah penelitian epidemiologi dengan menggunakan desain studi ekologi. Unit observasi dan analisis pada penelitian ini adalah 33 provinsi yang ada di Indonesia (kelompok atau agregat individu, komunitas atau populasi yang dibatasi secara geografik). Data berasal Riskesdas 2013. Agregrat data dari masing masing provinsi meliputi rasio puskesmas terhadap penduduk dan dokter per 1000 penduduk, Anggaran Pendapatan dan Belanja Daerah(APBD) untuk kesehatan,faktor risiko hipertensi (merokok dan aktifitas fisik) prevalensi diabetes mellitusdan prevalensi hipertensi.

Variabel dalam penelitian ini adalah variabel dependent prevalensi hipertensi di 33 provinsi di Indonesia sedangkan variabel independent adalah sistem kesehatan (pelayananan kesehatan, tenaga kesehatan, keuangan), faktor risiko hipertensi ( merokok dan aktifitas fisik) dan diabetes mellitus.

Analisis data deskripstif dilakukan untuk menggambarkan variabel prevalensi hipertensi di 33 provinsi di Indonesia, jumlah 
puskesmas dan rasionya terhadap penduduk, jumlah dokter per 100.000 penduduk, APBD, merokok, aktifitas fisik sedentary dan prevalensi diabetes mellitus dalam bentuk distribusi frekuensi, rata, simpangan baku (SB) dan rentang. Dilakukan analisis regresi linier dan analisis regresi linier gandaantara sistem kesehatan, faktor risiko hipertensi dan prevalensi diabetes dengan prevalensi hipertensi di 33 provinsi di Indonesia

Secara statistik perbedaan bermakna bila nilai $\mathrm{p}<0,05$. Semua analisis dilakukan menggunakan SPSS.ver. 22.

\section{HASIL}

Prevalensi hipertensi diberbagai provinsi diIndonesia bervariasi dari prevalensi terendah di papua 16.80, Bali 19.9 dan Riau 20.9 dan prevalensi tertinggi di kepulauan Bangka Belitung 30.90 kemudian diikuti oleh Kalimantan Selatan 30.80. Prevalensi rata-rata hipertensi (SD) di Indonesia sebesar 24.682 (3.449).

Berdasarkan jumlah Puskesmas di berbagai provinsi maka rasio puskesmas per 30.000 penduduk yang terendah adalah 0.60 yaitu di Banten dan tertinggi tertinggi 5,07 di Papua Barat. Untuk rata- rata jumlah dokter dan perawat per 100.000 penduduk adalah 201,600. Empat provinsi mempunyai jumlah dokter dan perawat terbanyak lebih dari 300 per 100.000 penduduk yaitu DKI Jakarta 349,60, Papua Barat 342,80, Sulawesi Utara 323,00 dan Maluku 318,80 sedangkan provinsi yang hanya memiliki jumlah dokter dan perawat kurang dari 110 adalah Jawa Barat 101,30, Lampung 105,3 dan Bali 107,5. Rerata APBD menurut fungsi kesehatan dalam $\%$ di 33 provinsi di Indonesia bervariasi mulai dari 1,95 di Provinsi Papua sampai 15,95 di provinsi Kalimatan Selatan.

Untuk rata- rata jumlah dokter dan perawat per 100.000 penduduk adalah 201,600. Empat provinsi mempunyai jumlah dokter dan perawat terbanyak lebih dari 300 per 100.000 penduduk yaitu DKI Jakarta 349,60, Papua Barat 342,80, Sulawesi Utara 323,00 dan Maluku 318,80 sedangkan provinsi yang hanya memiliki jumlah dokter dan perawat kurang dari 110 adalah Jawa Barat 101,30, Lampung 105,3 dan Bali 107,5.

Rerata APBD menurut fungsi kesehatan dalam \% di 33 provinsi di Indonesia bervariasi mulai dari 1,95 di Provinsi Papua sampai 15,95 di provinsi Kalimatan Selatan.

Prevalensi diabetes mellitus tertinggi sebesar 2.60 ditemukan di Daerah Istimewa Yogyakarta sedangkan urutan kedua ditempati oleh DKI Jakarta dengan prevalensi sebesar 2.50. sedangkan prevalensi DM terendah didapatkan di Lampung. Kemudian dikuti dengan Sulawesi Barat dengan prevalensi DM sebesar 0.80 .

Dari 33 provinsi yang ada di Indonesian ada 3 provinsi yang memiliki presentase tertinggi berkaitan aktivitas sedentary lebih dari 6 jam yaitu Riau, Maluku Utara, Jawa Timur, (39.10, 34.50,33.90) sedangkan Sulawesi Tenggara merupakan provinsi dengan aktivitas sedentarilebih 6 jam terendah di indonesia dengan presentase 3.10.

Deskripsi dari sistem kesehatan, faktor risiko hipertensi dan prevalensi diabetes dengan prevalensi hipertensi di 33 provinsi di Indonesia bisa dilihat pada tabel 1 . 
Tabel 1. Distribusi Frekuensi Prevalensi hipertensi , Sistem Kesehatan, Faktor Resiko Hipertensi dan prevalensi DM di 33 Provinsi di Indonesia

\begin{tabular}{lrr}
\hline Karakteristik & Rata-rata (SB) & \multicolumn{1}{c}{ Rentang } \\
\hline Prevalensi hipertensi (per 100.000 penduduk) & $24.682(3,449)$ & $16,80-30.90$ \\
Jumlah Puskesmas (Per 30.000 Penduduk) & $1.085(1.036)$ & $0.60-5,07$ \\
Jumlah dokter dan Perawat (Per 100.000 Penduduk) & $201,60(72,32)$ & $101,30-349,60$ \\
APBD menurut Fungsi Kesehatan( dalam \%) & $7,79(3,40)$ & $1,95-15,95$ \\
Prevalensi DM & $1.406(, 5315)$ & $0.70-2.60$ \\
Merokok & $23,809(2.657)$ & $16,30-27.20$ \\
Aktivitas sedentary lebih 6 jam & $19.876(9.216)$ & $3.10-39.10$
\end{tabular}
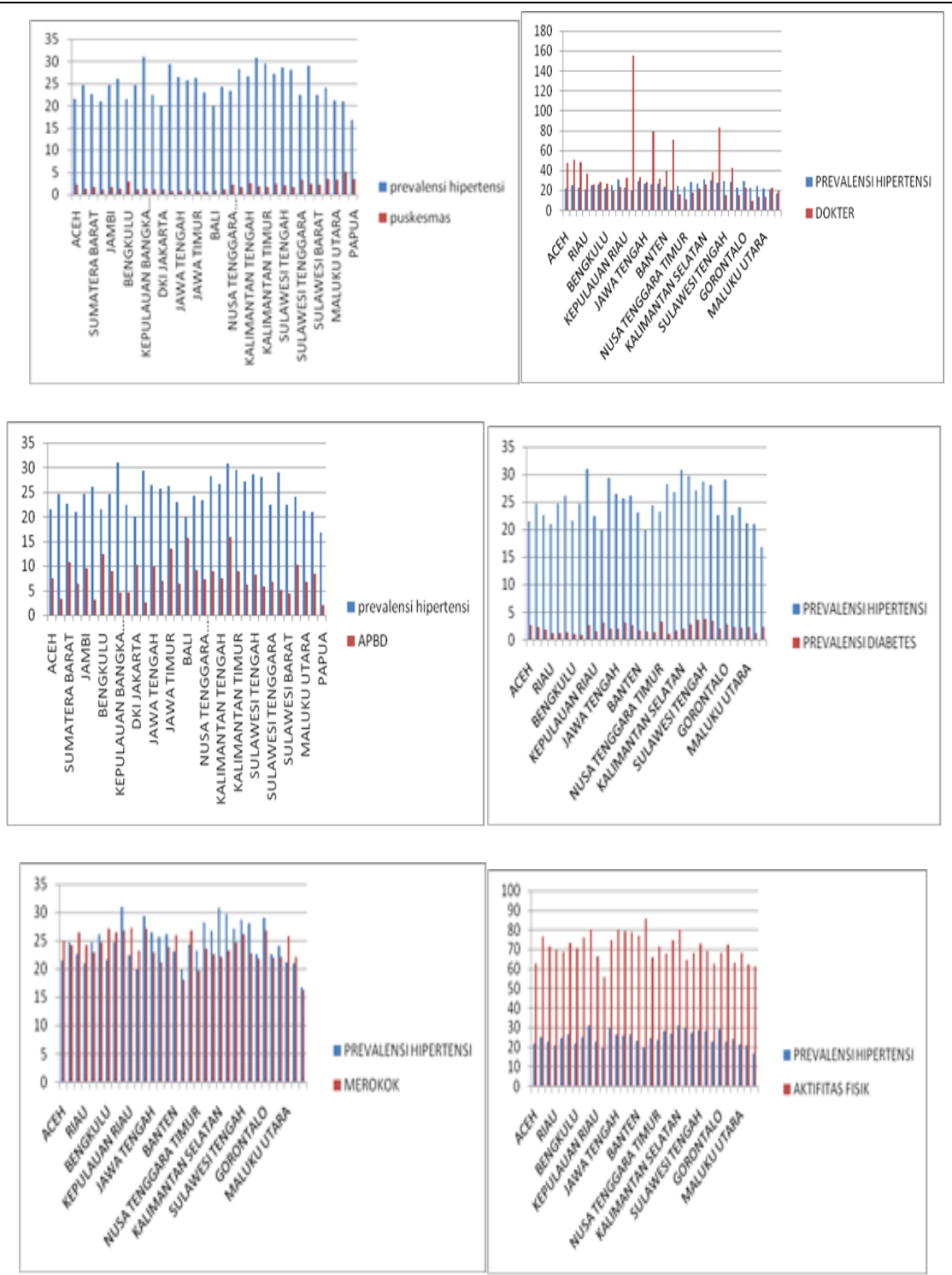

Gambar 1.Perbandingan Prevalensi Hipertensi dengan Sistem Kesehatan, Faktor Risiko Hipertensi dan Prevalensi DM 
Tabel 1 memperlihatkan bahwa prevalensi hipertensi menningkat dengan peningkatan aktifitas sedentari, peningkatan jumlah perokok disetiap pronpinsi demikian juga meningkatkan prevalensi hipertensi. Sedangkan jumlah pukesmas, dokter, perawat dan APBD tidak berpengaruh terhadaap prevalensi hipertensi.

Untuk melihat hubungan antara sistem kesehatan, faktor risiko hipertensi dan prevalensi diabetes mellitus dengan prevalensi hipertensi di 33 provinsi di Indonesia dilakukan analisis univariate dan multivariate dengan menggunakan regresi linier.

Hasil dari analisis regresi dapat dilihat pada tabel 2 di bawah ini. Pada model ini terdapat 2 variabel bebas yaitu merokok dan aktifitas fisik yang secara statistik signifikan berkorelasi dengan prevalensi hipertensi.

Table 2.Hasil analisis regresi linier dan regresi ganda antara sistem kesehatan, faktor risiko hipertensi dan prevalensi diabetes dengan prevalensi hipertensi di 33 provinsi di Indonesia

\begin{tabular}{|c|c|c|c|c|}
\hline Variabel & $\begin{array}{c}\text { Liner regresi } \\
\text { B (CI 95\%) }\end{array}$ & $\mathbf{P}$ & $\begin{array}{c}\text { Regresi linier } \\
\text { berganda } \\
\text { B (CI 95\%) }\end{array}$ & $\mathbf{P}$ \\
\hline $\begin{array}{lr}\text { Jumlah } & \text { Puskesmas } \\
\text { (Per } & 30.000 \\
\text { Penduduk) } & \end{array}$ & $-1,033($ & 0.084 & $*$ & \\
\hline $\begin{array}{l}\text { Jumlah dokter dan } \\
\text { Perawat (Per } 100.000 \\
\text { Penduduk) }\end{array}$ &,$- 023(-0,067-0.022)$ & 0.302 & $*$ & \\
\hline $\begin{array}{lr}\text { APBD } & \text { menurut } \\
\text { Fungsi } & \text { Kesehatan( } \\
\text { dalam } \%) & \end{array}$ & $-0,184(-0,556-0,188)$ & 0.321 & $*$ & \\
\hline Prevalensi DM & $1,201(-0,354-2,755)$ & 0.125 & $*$ & \\
\hline Merokok & $0,474(0,022-0,962)$ & 0.040 & $0,463(0,042-0,884)$ & 0,032 \\
\hline $\begin{array}{l}\text { Aktivitas sedentary } \\
\text { lebih } 6 \text { jam }\end{array}$ & $0.201(0,024-0.377)$ & 0.027 & $0.196(0,030-0,362)$ & 0,022 \\
\hline
\end{tabular}

$\mathrm{R} 2=0.271 *$ Variables yang tidak memenuhi persyaratan $\mathrm{p}<0.05$ dimasukan dalam model regresi berganda

\section{PEMBAHASAN}

Hasil penelitian ini menunjukkan bahwa jumlah dokter di setiap provinsi tidak bermakna dan tidak berhubungan dengan peningkatan prevalensi hipertensi. Begitu juga dengan jumlah perawat di setiap provinsi menunjukkan hasil yang tidak bermakna terhadap peningkatan prevalensi hipertensi.

Rasio jumlah puskesmas di setiap provinsi juga tidak berpengaruh terhadap prevalensi hipertensi, karena peningkatan jumlah Puskesmas tidak secara langsung menggambarkan pemenuhan kebutuhan pelayanan kesehatan dasar di suatu wilayah dan aksesibilitas masyarakat terhadap pelayanan kesehatan dasar.
Untuk rata-rata APBD yang dianggarkan untuk fungsi kesehatan di 33 provinsi di Indonesia bervariasi mulai dari 1,95 di provinsi Papua sampai 15,95 di provinsi Kalimatan Selatan. Namun secara rata-rata keseluruhan hasilnya tidak bermakna sehingga tidak mempengaruhi prevalensi hipertensi di Indonesia.

Sedangkan hasil penelitian dari faktor risiko hipertensi berupa aktivitas fisik memberikan hasil yang bemakna yaitu $\mathrm{p}=$ 0.028. Aktivitas fisik sangat memengaruhi stabilitas tekanan darah. Pada orang yang tidak aktif melakukan kegiatan cenderung mempunyai frekuensi denyut jantung yang lebih tinggi sehingga menyebabkan otot 
jantung bekerja lebih keras ketika kontraksi. makin besar dan sering otot jantung memompa, maka makin besar tekanan yang dibebankan pada arteri sehingga tekanan darah akan meningkat ${ }^{9}$.

Sedangkan aktifitas fisik yang dilakukan secara teratur menyebabkan otot polos jantung menjadi lebih kuat sehingga daya tampungnya menjadi besar, kontraksi atau denyut jantung menjadi lebih kuat dan teratur. Elastisitas pembuluh darahnyapun akan bertambah karena adanya relaksasi dan vasodilatasi, sehingga menyebabkan timbunan lemak menjadi berkurang yang akhirnya dapat meningkatkan kontraksi otot dinding pembuluh darah ${ }^{10}$.

Faktor risiko hipertensi berupa merokok memberikan hasil yang signifikan yaitu 0,041. Merokok merupakan masalah yang terus berkembang dan belum dapat ditemukan solusinya di Indonesia sampai saat ini. Menurut data WHO tahun 2011, pada tahun 2007 Indonesia menempati posisi ke-5 dengan jumlah perokok terbanyak di dunia. Merokok dapat menyebabkan hipertensi akibat zat-zat kimia yang terkandung di dalam tembakau yang dapat merusak lapisan dalam dinding arteri, sehingga arteri lebih rentan terjadi penumpukan plak (arterosklerosis). Hal ini terutama disebabkan oleh nikotin yang dapat merangsang saraf simpatis sehingga memacu kerja jantung lebih keras dan menyebabkan penyempitan pembuluh darah, serta peran karbonmonoksida yang dapat menggantikan oksigen dalam darah dan memaksa jantung memenuhi kebutuhan oksigen tubuh ${ }^{3}$.

Pada penelitian yang telah banyak dilakukan, dijelaskan bahwa efek akut yang disebabkan oleh merokok antara lain meningkatkan denyut jantung dan tekanan darah dengan adanya peningkatan kadar hormon epinefrin dan norepinefrin karena aktivasi sistem saraf simpatis. Banyak penelitian juga mengatakan bahwa efek jangka panjang dari merokok adalah peningkatan tekanan darah karena adanya peningkatan zat inflamasi, disfungsi endotel, pembentukan plak, dan kerusakan vaskular ${ }^{11}$.

Subyek yang mempunyai kebiasaan merokok mempunya resiko mengalami hipertensi 2,7 kali lebih besar dibandingkan dengan subyek yang bukan perokok. Hasil penelitian ini sesuai dengan beberapa hasil penelitian yang menunjukan bahwa tekanan darah pada perokok lebih tinggi dari pada bukan perokok, seperti pada penelitian yang dilakukan oleh Niskanen et al menunjukan pria yang merokok lebih dari 20 batang perhari mempunyai resiko mengalami hipertensi 2 kali lebih besar dengan rasio $2,38^{12}$. Hasil serupa juga ditemukan pada penelitian yang telah dilakukan Hergens et al, di Swedia yang memaparkan bahwa 30\% subyek penelitiannya menghisap tembakau dan orang-orang yang menghisap tembakau tersebut memiliki odds ratio terhadap peningkatan tekanan darah sebesar 1,23 dibandingkan dengan yang tidak menghisap tembakau ${ }^{13}$.

Untuk prevalensi diabetes mellitus dalam penelitian ini tidak signifikan terhadap kejadian hipertensi yaitu $p=0,130$. Hasil penelitian ini berbeda dengan penelitian lain yang menyebutkan adanya kaitan yang erat antara diabetes mellitus terhadap kejadian hipertensi. Beberapa penelitian tersebut menyebutkan bahwa orang yang menderita DM terutama tipe 2 memiliki resiko 2 sampai 4 kali lebih rentan mengalami kematian karena kelainan kardiovaskular daripada orang yang tidak menderita DM dan hipertensi terjadi 2 kali lebih rentan pada pasien dengan DM dibandingkan non DM pada kelompok usia yang sama ${ }^{14}$. Hasil penelitian di Jordania tahun 2008 menemukan bahwa terjadinya hipertensi berkaitan erat dengan pertambahan usia dan lamanya menderita $\mathrm{DM}^{15}$. Begitu juga dengan beberapa penelitian yang dilakukan di beberapa puskesmas dan kota di Indonesia menunjukkan bahwa bahwa secara statistik 
DM meningkatkan resiko terjadinya hipertensi sebesar 1,7 kali sehingga terdapat hubungan yang bermakna antara DM dan kejadian hipertensi, dan individu yang mengalami DM cenderung mempunyai tekanan darah yang lebih tinggi ${ }^{16}$. Pada penelitian ini tidak memberikan hasil yang signifikan antara prevelansi DM dengan prevalensi hipertensi, karenadata yang didapat dari riskedas hanyalah data prevalensi DM di setiap provinsi di Indonesia tanpa mengukur lamanya pasien menderita DM, sedangkan terjadinya risiko hipertensi pada penderita DM berhubungan dengan lamanya seseorang menderita DM.

penelitian-penelitian terdahulu hanya dilakukan di kelompok tertentu misalnya kejadian pada lansia dan hanya pada lingkungan-lingkungan penelitian yang kecil seperti di kecamatan ataupun wilayah-wilayah Puskesmas. Sedangkan faktor risiko kejadian hipertensi di setiap provinsi bisa berbeda-beda dan yang paling berpengaruh adalah gaya hidup seperti kurangnya aktivitas fisik dan juga merokok.

\section{KESIMPULAN}

Terdapat hubungan yang signifikan antara aktifitas fisik dan merokok terhadap kejadian hipertensi di setiap provinsi di Indonesia.

\section{UCAPAN TERIMA KASIH}

Penelitian ini dapat terlaksanan dengan baik karena peran dan bantuan dari berbagai pihak yang telah membantu baik secara langsung maupun tidak langsung, untuk itu peneliti mengucapkan terimakasih kepada:

1. Ketua LPPM UNS yang telah menyetujui pelaksanaan penelitian mandiri aktif

2. Kementerian Kesehatan yang telah menyediakan data riset kesehatan dasar yang dapat di akses secara terbuka dan gratis

\section{DAFTAR PUSTAKA}

1. Kementerian Kesehatan. Infodatin Hipertensi. Jakarta: Pusat Data Dan Informasi Kementerian Kesehatan; 2014.

2. World Health Organization (WHO). A Global Brief On Hypertension: Silent Killer, Global Public Health Crises (World Health Day 2013). Geneva: WHO; 2013.

3. Gita S, Delmi S, Yuniar L. Hubungan Merokok Dengan Kejadian Hipertensi Pada Laki-Laki Usia 35-65 Tahun di Kota Padang. Jurnal Kesehatan Andalas 2015.

4. Kementerian Kesehatan Republik Indonesia. Riset Kesehatan Dasar 2013. Jakarta: Badan Penelitian dan Pengembangan Kesehatan; 2013

5. Kementerian Kesehatan Republik Indonesia. Profil Kesehatan Indonesia Tahun 2017. Jakarta: Pusat Data Dan Informasi Kementerian Kesehatan; 2018.

6. World Health Organization(WHO). Diabetes. 2018. Diakses pada tanggal 22 Februari 2019 https://www.who.int/newsroom/fact-sheets/detail/diabetes.

7. Marice Sihombing. Faktor yang Berhubungan dengan Hipertensi pada Penduduk Indonesia yang Menderita Diabetes Mellitus (Data Riskesdas 2013). Jakarta: Puslitbang Sumber Daya dan Pelayanan Kesehatan; 2017.

8. World Health Organization(WHO). Monitoring the Building Block of Health Systems: A Handbook of Indicators and Their Measurement Strategies. Geneva: World Health Orgnization; 2010.

9. Rina Andriani Harahap, R. Kintoko Rochadi, Sorimuda Sarumpaet. Pengaruh Aktivitas Fisik Terhadap Kejadian Hipertensi Pada Laki-laki Dewasa Awal (18-40 tahun) Di Wilayah Puskesmas Bromo Medan Tahun 2017. Universitas Sumatera Utara, Jurnal Muara Sains, Teknologi, Kedokteran, dan Ilmu Kesehatan ISSN 2579-6402 (Versi Cetak) Vol. 1, No. 2, Oktober 2017: hlm 68-73.

10. Rumsari Mutiarawati. Hubungan Antara Riwayat Aktivitas Fisik Dengan Kejadian Hipertensi Pada Usia 45-54 Tahun, Study Di Wilayah Kelurahan Tlogosari Kulon Semarang Tahun 2009. Jurusan Ilmu Kesehatan Masyarakat, Fakultas Ilmu Keolahragaan Universitas Negeri Semarang, 2009.

11. Eric Untaro. Hubungan Merokok Terhadap Kejadian Hipertensi. Fakultas Kedokteran Universitas Hasanudin 2017 
12. Niskanen L, Laaksonen DE, Nyyssönen K, Punnonen K, Valkonen VP, Fuentes R, Tuomainen TP, Salonen R, Salonen JT.. Inflamation, Abdominal Obesity, and Smoking as Predictors of Hypertension. Hypertension 2004.

13. Hergens, MP, M Lambe, G Pershagen dan Wye. Risk of Hypertension Amongst Swedish Male Snuff Users: A Prospective Study. J Intern Med 2008.

14. Grossman E, Messerli FH. Hypertension and Diabetes. Luke's-Roosevelt Hospital and Columbia University 2008; 45:82-83.

15. Mubarak FM, Froelicher ES, Jaddou, HY, Ajlouni KM. Hypertension Among 1000 Patients With Type 2 Diabetes Attending A National Diabetes Center In Jordan. Ann Saudi Med 2008; 28:346.

16. Yohanes Silih. Hubungan Antara Diabetes Mellitus Dengan Kejadian Hipertensi. Naskah Publikasi, Program Studi Pendidikan Dokter Universitas Tanjung Pura 2012. 